\title{
Pengaruh Hospitality Pendekatan Soft Skill Karyawan Terhadap Peningkatan Kualitas Pelayanan Hotel di Kota Makassar dan Pare-Pare, Sulawesi Selatan
}

\author{
Hamsiati* \\ Manajemen Tata Hidang \\ Politeknik Pariwisata Makassar, Jln Metro Tanjung Bunga Kota Makassar, Indonesia \\ Email: ati.akpar@gmail.com
}

\begin{abstract}
This study aims to analyze the relationship of employee hospitality with soft skills in intrapersonal, intrapersonal, attitudes and behaviors related to improving the quality of hotel services in Makassar City and Parepare; and analyze the application of hospitality with gentle expertise, which is dominant in improving the quality of hotel services in the cities of Makassar and Parepare. This research is a quantitative descriptive study describing factual conditions with data collected from questionnaires through direct collection of objects and interviews. The study population was hotel employees in the Food and Beverage Service (F\&B) section, and a sample of 38 respondents based on purposive sampling techniques. Descriptive data analysis through frequency and percentage, and statistical analysis using Multiple Linear Regression. The findings of this study are the hospitality of employees with intrapersonal, interpersonal, soft skills and attitudes that have been applied by employees and have a positive and significant influence both simultaneously and partially on improving the quality of hotel services in Makassar City and Parepare. The results of the analysis also showed that all variables collected consisted of intrapersonal, interpersonal, attitudes and significant behaviors based on the value of tcount> ttable, and were found to be related to the hospitality obtained by soft skills consisting of attitudes (X3) which were dominant in Makassar and Parepare. A value of 0.862 , which shows the same way as a hotel, is a hospitality that refers to soft skills, which determine the quality of hotel services in Makassar City and Parepare.
\end{abstract}

Keywords: Hospitality; Soft Skill; Intrapersonal; Interpersonal; Attitude; Behavior and Service Quality.

\begin{abstract}
Abstrak
Penelitian ini bertujuan untuk menganalisis pengaruh hospitality karyawan dengan pendekatan soft skill secara intrapersonal, intrapersonal, attitude dan behavior berpengaruh terhadap peningkatan kualitas pelayanan hotel di Kota Makassar dan Parepare; dan menganalisis diantara penerapan hospitality karyawan dengan pendekatan soft skill, yang dominan berpengaruh terhadap peningkatan kualitas pelayanan hotel di Kota Makassar dan Parepare. Penelitian ini adalah deskriptif kuantitatif yang mendeskripsikan kondisi faktual dengan data-data yang terkumpul dari kuesioner berdasarkan pengamatan langsung objek dan wawancara. Populasi penelitian adalah karyawan hotel bagian Food and Beverage Service (F\&B), dan sampel sebanyak 38 orang responden berdasarkan teknik purposive sampling. Analisis data secara deskriptif melalui frekuensi dan persentase, serta analisis secara statistik menggunakan Regresi Linier Berganda. Temuan penelitian ini yaitu hospitality karyawan dengan pendekatan soft skill secara intrapersonal, interpersonal, attitude dan behavior telah diterapkan karyawan dan memberikan pengaruh yang positif dan signifikan baik secara simultan maupun parsial terhadap peningkatan kualitas pelayanan hotel di Kota Makassar dan Parepare. Hasil analisis juga menunjukkan keseluruhan variabel yang diamati berupa intrapersonal, interpersonal, attitude dan behavior adalah signifikan berdasarkan perolehan nilai thitung $>t_{t a b e l}$, dan ditemukan pengaruh hospitality pendekatan soft skills berupa attitude $\left(\mathrm{X}_{3}\right)$ yang dominan berpengaruh atau yang lebih berpengaruh terhadap kualitas pelayanan hotel di Kota Makassar dan Parepare. Hal ini didasarkan pada koefisien regresi nilai B sebesar 0.862, yang menunjukkan cara bersikap dari karyawan hotel merupakan bentuk hospitality pendekatan soft skills yang menentukan kualitas pelayanan hotel di Kota Makassar dan Parepare.
\end{abstract}

Keywords: Hospitality, Soft Skill, Intrapersonal, Interpersonal, Attitude, Behavior dan Kualitas Pelayanan.

* Corresponding author

Received: April 02, 2020; Revised: April 07, 2020; Accepted: April 08, 2020 


\section{A. PENDAHULUAN}

Industri hotel memainkan peran yang sangat penting. Industri perhotelan memiliki pengaruh yang signifikan tidak hanya pada daya saing pariwisata tetapi juga pada pengembangan umum di suatu kawasan kota maupun negara (Musawantoro \& Ridwan, 2019; Suardana, Suni, \& Ridwan, 2019). Hotel juga mempunyai peran untuk mempromosikan potensi lokal yang ada di sekitarnya. Gordin (2016) mengemukakan bahwa restoran hotel memiliki potensi besar dalam mempromosikan keahlian memasak secara lokal (gastronomi). Yang paling utama adalah hotel sebagai akomodasi untuk menunjang usaha pariwisata pada sebuah destinasi. Hotel merupakan sarana persinggahan sementara bagi wisatawan termasuk diantaranya memberikan pelayanan kamar serta pelayanan makanan dan minuman, maka hal yang paling penting dari suatu produk hotel yaitu faktor manusia berupa jasa pelayanannya (Ivanovic. M., 2009).

Hotel sebagai media perantara antara wisatawan dengan destinasi wisata. Peran hotel tidak hanya sebagai amenitas yang kegiatan utamanya menjual kamar, namun karena intensitasnya yang berhubungan secara langsung dengan wisatawan maka pihak hotel memiliki peran sebagai perantara (Sinangjoyo, 2013). Tujuan wisatawan datang berkunjung pada suatu tempat bukanlah untuk tidur di hotel semata-mata. Menginapnya wisatawan di hotel dan akomodasi lainnya selalu dikaitkan dengan keperluan lain dengan motivasi yang beraneka ragam. Dengan perkataan lain, sektor perhotelan bukan suatu hal yang mutlak harus ada. Tanpa hotel orang - orang juga dapat menikmati banyak obyek dan atraksi wisata. Akomodasi perhotelan tidak dapat dipisahkan dengan pariwisata. Tanpa kegiatan kepariwisataan dapat dikatakan akomodasi perhotelan belum lengkap. Sebaliknya pariwisata tanpa hotel merupakan suatu hal yang tidak mungkin. Hotel termasuk sarana pokok kepariwisataan (main tourism superstructures). Ini berarti kelangsungan hidup dunia perhotelan banyak tergantung pada banyak atau sedikitnya wisatawan yang datang. Diumpamakan industri pariwisata itu sebagai suatu bangunan, maka sektor perhotelan merupakan tiangnya.

Industri pariwisata seperti hotel dan restoran akhir-akhir ini semakin berkembang yang menuntut suatu penciptaan suasana yang nyaman dari berbagai aspek untuk diberikan atau ditawarkan sebagai suatu produk kepada calon pelanggannya. Secara umum, produk yang dijual oleh pihak manajemen hotel terdiri dari dua produk utama yaitu produk nyata (tangible product) seperti kamar hotel, restoran, spa, dan berbagai fasilitas hotel lainnya dan produk tidak nyata (intangible product) seperti kenyamanan, pelayanan, suasana dan lain sebagainya (Prastowo, 2017).

Dalam menghadapi persaingan di era global perusahaan bidang perhotelan dituntut untuk bekerja lebih efisien dan efektif. Persaingan yang semakin ketat menyebabkan perhotelan dituntut untuk mampu meningkatkan daya saing dalam rangka memberi jaminan kepuasan kepada pelanggan. Ahmad (2019) menyatakan bahwa untuk mencapai tingkat kepuasan yang tinggi diperlukan adanya pemahaman tentang apa yang diinginkan oleh konsumen, dengan mengembangkan komitmen setiap orang yang ada dalam lembaga untuk memenuhi kebutuhan konsumen. Karena kualitas pelayanan konsumen sebagai ukuran kualitas layanan. Zaenal (2018) mengemukakan bahwa kualitas pelayanan yang dirasakan menjelaskan sebagian besar varians terhadap service value, dan nilai yang dirasakan adalah ukuran yang baik terhadap evaluasi menyeluruh oleh pengunjung terhadap kualitas layanan dari pada kualitas pelayanan yang dirasakan. Dengan demikian, perusahaan harus mempunyai perencanaan sumber daya manusia, sebagai suatu keharusan untuk memberikan pelayanan yang terbaik dan kualifikasinya sesuai pemenuhan kepuasan yang menjadi bagian penting dalam persaingan global perhotelan saat ini.

Hospitality adalah istilah yang digunakan untuk industri pariwisata dengan kegiatan utama berhubungan dengan keramah-tamahan, pelayanan, dan hiburan. Di dalam sebuah organisasi seperti industri hotel merupakan salah satu industri pariwisata yang menyediakan fasilitas penginapan dan memberikan pelayanan makanan dan minuman dikenal dengan istilah Food and Beverage Service (FBS), 
yaitu salah satu bagian hotel yang bertanggung jawab dalam menyajikan makanan dan minuman kepada tamu secara profesional dengan tujuan mendapatkan income atau revenue dan profit.

Menurut Soekarno (1998) Food and Beverage Department adalah bagian dari hotel yang mengurus dan bertanggung jawab terhadap kebutuhan pelayanan makanan dan minuman serta kebutuhan lain yang terkait, dari para tamu yang tinggal maupun yang tidak tinggal di hotel tersebut dan dikelola secara komersial serta professional untuk menhasilkan pendapatan. Sehingga dapat dikatakan Food and Beverage Service ini memegang peranan penting dalam suatu hotel, karena baik buruknya, berhasil tidaknya dan populer tidaknya suatu hotel, juga dipengaruhi oleh Food and Beverage Service (F\&B).

Mengingat pentingnya keberadaan pelayanan F\&B dalam sebuah hotel, maka diperlukan sumber daya manusia yang memberikan pelayanan dengan penuh pemahaman tentang hospitality yaitu orang yang memberikan pelayanan penuh keramahtamahan sesuai dengan kemampuan atau keahlian (skill) yang dimiliki. Bisa berupa soft skill maupun hard skill. Hard skill biasanya mengacu pada kemampuan yang berasal dari pengetahuan, kemampuan praktis, atau kecerdasan untuk melakukan sesuatu dengan baik; kompetensi dalam melakukan sesuatu; keahlian atau keterampilan yang membutuhkan latihan tertentu (Rotmianto, 2016). Pelayanan hospitality yang menggunakan pendekatan soft skill yaitu seseorang yang memiliki kemampuan untuk memahami diri sendiri (intrapersonal) dan memposisikan diri (interpersonal) yang ditunjukkan oleh cara bersikap (attitude) dan berperilaku (behavior) sehingga memiliki ketahanan mental untuk dapat membina atau menjalin hubungan yang baik dengan orang lain atau tamu yang dilayani dalam mengembangkan dirinya atas pekerjaan yang ditekuninya

Soft skill atau keterampilan generik adalah kemampuan seseorang untuk mencapai kesuksesan dalam hidup dalam konteks lingkungan sosial-budaya (Curtis, 2010; Talavera \& Pérez-González, 2007). Soft skill adalah keterampilan intrapersonal dan interpersonal atau sosio-emosional yang penting untuk pengembangan pribadi, partisipasi sosial dan keberhasilan dalam bekerja yang mencakup keterampilan seperti kemampuan untuk bekerja di tim multidisiplin, komunikasi, kesadaran budaya dan ekspresi, ketekunan, kemampuan beradaptasi, dan kejujuran (Kechagias, 2011). Seseorang orang memiliki hospitality pendekatan soft skill harus mampu mengembangkan segala potensi yang dimilikinya untuk mampu memberikan pelayanan yang terbaik kepada tamu hotel dalam meningkatkan kualitas pelayanannya. Dengan demikian, menjadi penting bagi seorang karyawan hotel untuk memiliki hospitality yang memahami dirinya sendiri (intrapersonal) yaitu dengan memiliki kemampuan kedisiplinan dan tanggungjawab pada pekerjaan yang ditekuni sebagai seorang yang menguasai bidang F\&B.

Seorang karyawan hotel harus mampu memposisikan dirinya (interpersonal) dengan selalu mengembangkan kemampuan inisiatif dan kreativitas dalam menjalankan tugas menyajikan makanan dan minuman secara profesional. Mampu mengembangkan cara bersikap (attitude) yang baik dengan menunjukkan motivasi dan semangat kerja, khususnya dalam melayani tamu hotel sesuai pesan pelayanan makanan dan minuman yang dibutuhkan. Termasuk karyawan harus mampu mengaktualisasikan perilaku (behavior) dalam bekerja dengan menjalin kerjasama, sosialisasi dan berkomunikasi. Hospitality pendekatan soft kill yang dimiliki oleh seorang karyawan hotel sangat penting di dalam menjalankan keberlangsungan kegiatan pelayanan hotel khususnya karyawan yang bekerja di bagian F\&B service untuk meningkatkan kualitas pelayanan hotel. Keberhasilan kualitas pelayanan dapat dilihat dari kepuasan tamu hotel di dalam mendapatkan pelayanan yang handal (reliability), terjamin (assurance), memiliki bukti fisik (tangible), selalu berempati melayani (empathy) dan dan tanggap (responsiveness) atas pelayanan yang dibutuhkan oleh tamu hotel.

Penelitian tentang pengaruh kualitas pelayanan pada kepuasan pelanggan hotel menunjukkan bahwa kualitas pelayanan yang terdiri atas lima dimensi yaitu bukti fisik, kehandalan, daya tanggap, 
jaminan, dan empati secara simultan berpengaruh signifikan pada kepuasan pelanggan Hotel Bintang Pesona di Denpasar Timur dan kualitas pelayanan yang terdiri atas lima dimensi tersebut secara parsial berpengaruh signifikan pada kepuasan pelanggan Hotel Bintang Pesona di Denpasar Timur (Suryadharma \& Nurcahya, 2015). Sementara untuk pentingnya kompetensi dan kebutuhan soft skill karyawan hotel sebuah penelitian Mahfud dan Mulyani (2017) membuktikan bahwa bahwa investasi kompetensi soft skill sangat penting dan menjadi modal yang diperlukan seseorang dalam mengaktualisasikan dirinya untuk bekerja terutama dalam pelaksanaan program magang. Sepuluh prioritas kebutuhan kompetensi soft skill di bagian F\&B Production pada program magang di sektor industri perhotelan Balikpapan mencakup kemampuan untuk bekerja sama, fokus dalam melakukan pekerjaan, kemampuan komunikasi, kejujuran, tanggung jawab, kreativitas, inisiatif kerja, disiplin, kesopanan, dan kehati-hatian. Sementara sepuluh prioritas utama perlu pada kompetensi soft skill dalam Layanan F\&B termasuk kejujuran, kesopanan, keterampilan komunikasi, responsif terhadap kebutuhan konsumen, tanggung jawab, fokus dalam melakukan pekerjaan, kerja sama, disiplin, kepercayaan diri, dan inisiatif kerja. Proses pengembangan kompetensi soft skill dalam pelaksanaan program pemagangan diberikan secara teoritis pada tahap pra-pemagangan dan diimplementasikan pada tahap kegiatan pemagangan di industri perhotelan. Daya serap pekerja magang mencapai $72 \%$.

Adapun penelitian tentang kurang puasnya konsumen terhadap kemampuan/ skill karyawan hotel. Fitria dan Atalina (2016) mengemukakan bahwa skill dan menu knowledge yang dimiliki waiter dan waitress masih dianggap kurang, hal ini dibuktikan dengan hasil kuisioner pada waiter/ waitress yang sebagian masih kurang terampil dan kurang mengetahui menu knowledge. Hal ini berdampak pada menurunya kepuasan pelanggan restoran dibuktikan dengan hasil kuisioner yang menunjukan sebagian pelanggan di restoran masih merasa kurang puas atas skill dan menu knowledge yang dimiliki waiter/ waitres

Berdasarkan latar belakang di atas, maka penelitian ini berjudul Pengaruh Hospitality Pendekatan Soft Skill Karyawan Terhadap Peningkatan Kualitas Pelayanan Hotel Di Kota Makassar dan Pare-Pare, Sulawesi Selatan. Penelitian ini bertujuan untuk mengetahui Pengaruh Hospitality dengan menggunakan pendekatan soft skill karyawan yang dilakukan pada hotel yang berada di Kota Makassar dan Pare-pare, Sulawesi Selatan.

\section{B. METODE PENELITIAN}

Jenis penelitian adalah deskriptif kualitatif dengan objek dalam penelitian ini adalah karyawan hotel untuk melihat penerapan hospitality melalui pendekatan soft kill dari karyawan hotel di Kota Makassar dan Parepare. Data ini menggunakan jenis data primer yang diperoleh dengan menggunakan metode deskriptif kualitatif yang akan mendeskripsikan kondisi faktual tersebut dengan data-data yang telah dikumpulkan melalui kata-kata tertulis, atau lisan dari orang-orang dan prilaku yang diamati melalui pengamatan langsung obyek atau observasi dan wawancara.

Populasi pada hakekatnya adalah keseluruhan obyek yang diteliti, dimana penelitian ini yang menjadi populasi penelitian adalah karyawan hotel di Kota Makassar dan Parepare sebagai perbandingan. Karena penelitian ini menyangkut tentang hospitality melalui pendekatan soft skill dari karyawan hotel, maka populasi hanya dikhususkan pada karyawan bagian Food and Beverage Service (F\&B). Populasi penelitian ini cukup besar maka digunakan sampel dengan teknik sampling menggunakan purposive sampling. Pengambilan purposive sampling dilakukan dengan mengambil sampel dari populasi berdasarkan suatu kriteria tertentu (Sugiyono, 2010). Peneliti menggunakan purposive sampling untuk responden dipilih berdasarkan tujuan atau informasi yang ingin didapat. Artinya tujuan/informasi yang ingin didapat akan menentukan responden yang tepat dan kompeten untuk memberikan informasi yang dibutuhkan. Jumlah responden sangat fleksibel tergantung dari informasi yang didapatkan. Dengan 
demikian kriteria pemilihan responden dilakukan pada hotel berbintang 4 dan 5 yang berada di wilayah Kota Makassar dan Pare-pare, Hotel tersebut sebagai anggota PHRI, karyawan memiliki bukti bekerja dari Head Divisi dan/atau sertifikat kompetensi yang legal. Sedangkan yang menjadi sampelnya yaitu populasi itu sendiri sebanyak 38 karyawan dari 20 hotel.

Untuk memperoleh data primer, alat penelitian yang digunakan adalah pedoman observasi dan wawancara dengan indikator yang ada, serta kuesioner yang mendukung data penelitian dengan cara menyebarkan kepada responden terpilih untuk mendapatkan data opini individu masing-masing. Dalam analisa data, kategori sumber data yang menghasilkan data penelitian kemudian dianalisa secara deskriptif melalui frekuensi dan persentase, serta secara statistik menggunakan regresi linier berganda.

\section{HASIL DAN ANALISIS}

Penelitian tentang hospitality pendekatan soft skill karyawan dalam meningkatkan kualitas pelayanan hotel di Kota Makassar dan Parepare. Adapun yang dijadikan responden dalam penelitian ini adalah 38 orang karyawan yang kompeten dalam memberikan informasi yang dibutuhkan. Responden ini diambil secara purposive sampling. Lebih jelasnya hasil penelitian diuraikan pada tabel 1.

Tabel 1 Rekapitulasi Jawaban Responden tentang Intrapersonal

\begin{tabular}{|c|c|c|c|c|c|c|c|c|c|c|c|}
\hline \multirow{3}{*}{ Pernyataan } & \multicolumn{10}{|c|}{ Kualitas Pelayanan Hotel } & \multirow{3}{*}{ Skor } \\
\hline & \multicolumn{2}{|l|}{ SB } & \multicolumn{2}{|l|}{$\mathrm{B}$} & \multicolumn{2}{|l|}{$\mathrm{KB}$} & \multicolumn{2}{|c|}{ ТВ } & \multicolumn{2}{|c|}{ STB } & \\
\hline & $\Sigma$ & $\%$ & $\Sigma$ & $\%$ & $\Sigma$ & $\%$ & $\Sigma$ & $\%$ & $\Sigma$ & $\%$ & \\
\hline Intra1 & 26 & 68.4 & 12 & 31.6 & 0 & 0.0 & 0 & 0.0 & 0 & 0.0 & 178 \\
\hline Intra2 & 17 & 44.7 & 21 & 55.3 & 0 & 0.0 & 0 & 0.0 & 0 & 0.0 & 169 \\
\hline Intra3 & 26 & 68.4 & 12 & 31.6 & 0 & 0.0 & 0 & 0.0 & 0 & 0.0 & 178 \\
\hline Intra4 & 18 & 47.4 & 20 & 52.6 & 0 & 0.0 & 0 & 0.0 & 0 & 0.0 & 170 \\
\hline Total Skor & & & & & & & & & & & 695 \\
\hline Rata-rata & & & & & & & & & & & 173.8 \\
\hline
\end{tabular}

Sumber: Kuesioner Penelitian, 2019

Tabel 1 tanggapan responden terhadap hospitality pendekatan soft skills karyawan berdasarkan intrapersonal dengan total skor 695 atau rata-rata 173.8 dari 4 item pernyataan yang didapatkan dari 2 indikator. Adapun skor tertinggi untuk setiap item pernyataan diberi skor 5 dan skor terendah diberi skor 1. Adapun skor maksimum untuk intrapersonal sebagai berikut:

Skor Maksimum = Skor Tertinggi Item Pernyataan $\mathrm{x} \mathrm{N}$ Item Pernyataan

$$
\begin{aligned}
& =\text { Skor Tertinggi (5) x N (38) x Item Pernyataan (4) } \\
& =5 \times 38 \times 4 \\
& =760
\end{aligned}
$$

Berdasarkan penelitian hospitality pendekatan soft skills karyawan berupa intrapersonal dalam meningkatkan kualitas pelayanan hotel di Kota Makassar dan Parepare, diperoleh total skor 695, maka tanggapan dari 38 responden atas hal tersebut yaitu:

Skor Perolehan 695

------------- x 100\% = ----- x 100\% = 91.4\%

Skor Maksimum

760 
Penilaian hospitality pendekatan soft skills karyawan berupa intrapersonal dalam meningkatkan kualitas pelayanan hotel sebesar $91.4 \%$, secara kontinum dapat dibuat kategori sebagai berikut:

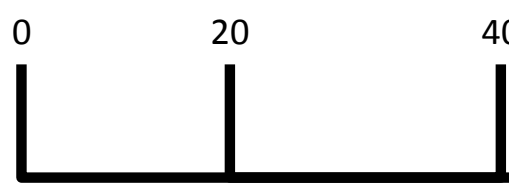

STB

TB

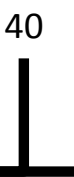

KB

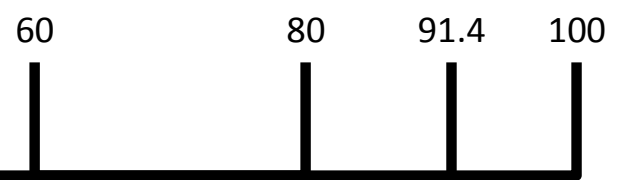

B SB

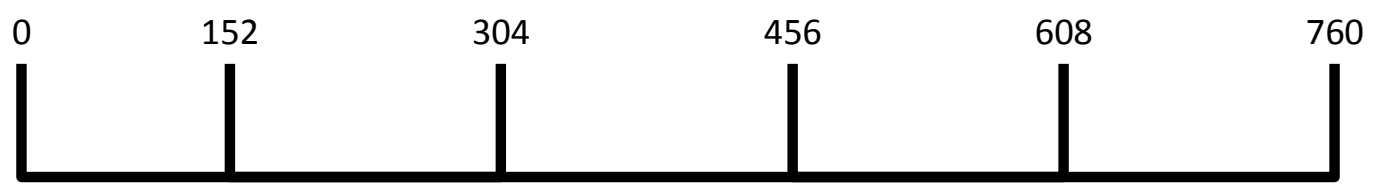

STB TB

KB

B

SB

Keterangan:

Sangat Baik

: $5 \times 38 \times 4=760$

Baik

$: 4 \times 38 \times 4=608$

Kurang Baik

$: 3 \times 38 \times 4=456$

Tidak Baik

: $2 \times 38 \times 4=304$

Sangat Tidak Baik

: 1 x $38 \times 4=152$

Hasil analisis di atas menunjukkan bahwa hospitality pendekatan soft skills karyawan berupa intrapersonal berada pada kategori yang memberikan pengaruh dalam meningkatkan kualitas pelayanan hotel di Kota Makassar dan Parepare.

Tabel 2 Rekapitulasi Jawaban Responden tentang Interpersonal

\begin{tabular}{|c|c|c|c|c|c|c|c|c|c|c|c|}
\hline \multirow{3}{*}{ Pernyataan } & \multicolumn{10}{|c|}{ Kualitas Pelayanan Hotel } & \multirow{3}{*}{ Skor } \\
\hline & \multicolumn{2}{|c|}{ SB } & \multicolumn{2}{|c|}{$\mathrm{B}$} & \multicolumn{2}{|c|}{ KB } & \multicolumn{2}{|c|}{ TB } & \multicolumn{2}{|c|}{ STB } & \\
\hline & $\Sigma$ & $\%$ & $\Sigma$ & $\%$ & $\Sigma$ & $\%$ & $\Sigma$ & $\%$ & $\Sigma$ & $\%$ & \\
\hline Inter1 & 26 & 68.4 & 12 & 31.6 & 0 & 0.0 & 0 & 0.0 & 0 & 0.0 & 178 \\
\hline Inter2 & 26 & 68.4 & 12 & 31.6 & 0 & 0.0 & 0 & 0.0 & 0 & 0.0 & 178 \\
\hline Inter3 & 27 & 71.1 & 11 & 28.9 & 0 & 0.0 & 0 & 0.0 & 0 & 0.0 & 179 \\
\hline Inter4 & 17 & 44.7 & 21 & 55.3 & 0 & 0.0 & 0 & 0.0 & 0 & 0.0 & 169 \\
\hline \multicolumn{11}{|c|}{ Total Skor } & 704 \\
\hline \multicolumn{11}{|c|}{ Rata-rata } & 176.0 \\
\hline
\end{tabular}

Sumber: Kuesioner Penelitian, 2019

Tabel 2 tanggapan responden terhadap hospitality pendekatan soft skills karyawan berdasarkan interpersonal dengan total skor 704 atau rata-rata 176 dari 4 item pernyataan yang didapatkan dari 2 indikator. Adapun skor tertinggi untuk setiap item pernyataan diberi skor 5 dan skor terendah diberi skor 1. Adapun skor maksimum untuk interpersonal sebagai berikut:

Skor Maksimum = Skor Tertinggi Item Pernyataan $\mathrm{x} \mathrm{N}$ x Item Pernyataan

$$
\begin{aligned}
& =\text { Skor Tertinggi (5) x N (38) x Item Pernyataan (4) } \\
& =5 \times 38 \times 4 \\
& =760
\end{aligned}
$$


Berdasarkan penelitian hospitality pendekatan soft skills karyawan berupa interpersonal dalam meningkatkan kualitas pelayanan hotel di Kota Makassar dan Parepare, diperoleh total skor 704, maka tanggapan dari 38 responden atas hal tersebut yaitu:

Skor Perolehan 704

Skor Maksimum $\quad 760$

Penilaian hospitality pendekatan soft skills karyawan berupa interpersonal dalam meningkatkan kualitas pelayanan hotel sebesar 92.6\%, secara kontinum dapat dibuat kategori sebagai berikut:

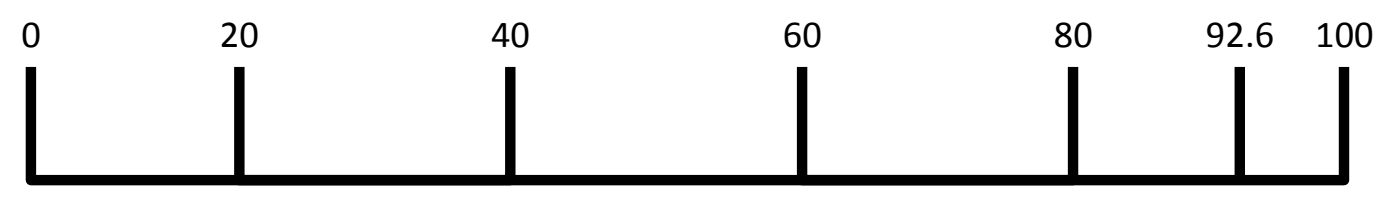

$\begin{array}{lllll}\text { STB } & \text { TB } & \text { KB } & \text { B } & \text { SB }\end{array}$

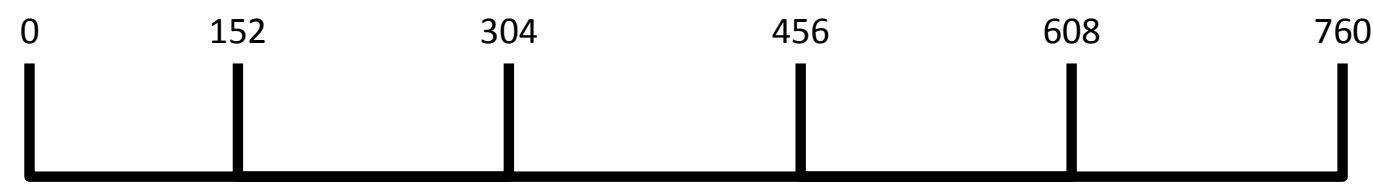

STB

TB

KB

B

SB

Keterangan:

Sangat Baik

: $5 \times 38 \times 4=760$

Baik

: $4 \times 38 \times 4=608$

Kurang Baik

: $3 \times 38 \times 4=456$

Tidak Baik

Sangat Tidak Baik

$$
\text { : } 2 \text { × } 38 \times 4=304
$$

$: 1 \times 38 \times 4=152$

Hasil analisis di atas menunjukkan bahwa hospitality pendekatan soft skills karyawan berupa interpersonal berada pada kategori yang memberikan pengaruh dalam meningkatkan kualitas pelayanan hotel di Kota Makassar dan Parepare.

Tabel 3 Rekapitulasi Jawaban Responden tentang Attitude

\begin{tabular}{|c|c|c|c|c|c|c|c|c|c|c|c|}
\hline \multirow{3}{*}{ Pernyataan } & \multicolumn{10}{|c|}{ Kualitas Pelayanan Hotel } & \multirow{3}{*}{ Skor } \\
\hline & \multicolumn{2}{|c|}{ SB } & \multicolumn{2}{|c|}{$\mathrm{B}$} & \multicolumn{2}{|c|}{ KB } & \multicolumn{2}{|c|}{ TB } & \multicolumn{2}{|c|}{ STB } & \\
\hline & $\Sigma$ & $\%$ & $\Sigma$ & $\%$ & $\Sigma$ & $\%$ & $\Sigma$ & $\%$ & $\Sigma$ & $\%$ & \\
\hline Attitude 1 & 17 & 44.7 & 21 & 55.3 & 0 & 0.0 & 0 & 0.0 & 0 & 0.0 & 169 \\
\hline Attitude2 & 26 & 68.4 & 12 & 31.6 & 0 & 0.0 & 0 & 0.0 & 0 & 0.0 & 178 \\
\hline Attitude3 & 26 & 68.4 & 12 & 31.6 & 0 & 0.0 & 0 & 0.0 & 0 & 0.0 & 178 \\
\hline Attitude4 & 27 & 71.1 & 11 & 28.9 & 0 & 0.0 & 0 & 0.0 & 0 & 0.0 & 179 \\
\hline \multicolumn{11}{|c|}{ Total Skor } & 704 \\
\hline \multicolumn{11}{|c|}{ Rata-rata } & 176.0 \\
\hline
\end{tabular}

Sumber: Kuesioner Penelitian, 2019 
Tabel 3 tanggapan responden terhadap hospitality pendekatan soft skills karyawan berdasarkan attitude dengan total skor 704 atau rata-rata 176 dari 4 item pernyataan yang didapatkan dari 2 indikator. Adapun skor tertinggi untuk setiap item pernyataan diberi skor 5 dan skor terendah diberi skor 1 . Adapun skor maksimum untuk interpersonal sebagai berikut:

Skor Maksimum = Skor Tertinggi Item Pernyataan x N x Item Pernyataan

$$
\begin{aligned}
& =\text { Skor Tertinggi (5) x N (38) x Item Pernyataan (4) } \\
& =5 \times 38 \times 4 \\
& =760
\end{aligned}
$$

Berdasarkan penelitian hospitality pendekatan soft skills karyawan berupa attitude dalam meningkatkan kualitas pelayanan hotel di Kota Makassar dan Parepare, diperoleh total skor 704, maka tanggapan dari 38 responden atas hal tersebut yaitu:

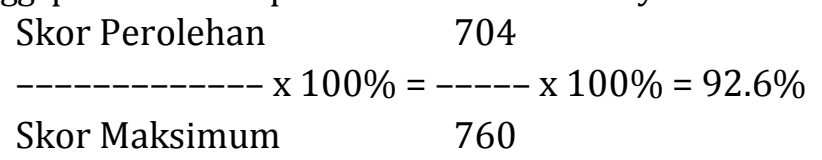

Penilaian hospitality pendekatan soft skills karyawan berupa attitude dalam meningkatkan kualitas pelayanan hotel sebesar 92.6\%, secara kontinum dapat dibuat kategori sebagai berikut:

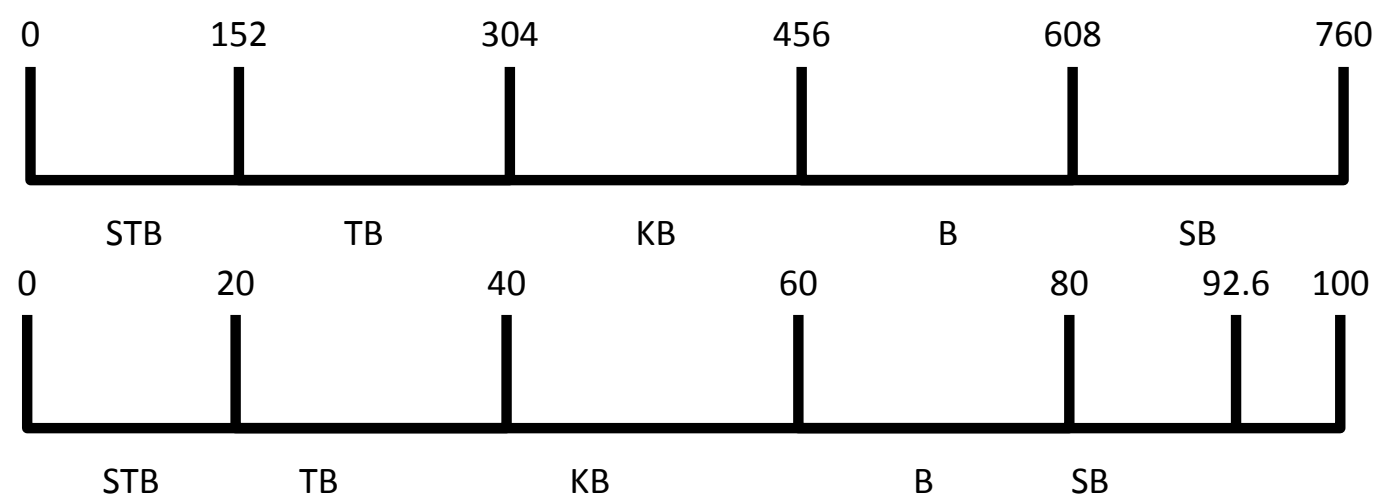

Keterangan:

Sangat Baik

$: 5 \times 38 \times 4=760$

Baik

$: 4 \times 38 \times 4=608$

Kurang Baik

$: 3 \times 38 \times 4=456$

Tidak Baik

Sangat Tidak Baik

$$
: 2 \times 38 \times 4=304
$$

$: 1 \times 38 \times 4=152$

Hasil analisis di atas menunjukkan bahwa hospitality pendekatan soft skills karyawan berupa

\begin{tabular}{|c|c|c|c|c|c|c|c|c|c|c|c|}
\hline \multirow{3}{*}{ Pernyataan } & \multicolumn{10}{|c|}{ Kualitas Pelayanan Hotel } & \multirow{3}{*}{ Skor } \\
\hline & \multicolumn{2}{|c|}{ SB } & \multicolumn{2}{|c|}{ B } & \multicolumn{2}{|c|}{ KB } & \multicolumn{2}{|c|}{ TB } & \multicolumn{2}{|c|}{ STB } & \\
\hline & $\Sigma$ & $\%$ & $\Sigma$ & $\%$ & $\Sigma$ & $\%$ & $\Sigma$ & $\%$ & $\Sigma$ & $\%$ & \\
\hline Behavior1 & 26 & 68.4 & 12 & 31.6 & 0 & 0.0 & 0 & 0.0 & 0 & 0.0 & 178 \\
\hline Behavior2 & 17 & 44.7 & 21 & 55.3 & 0 & 0.0 & 0 & 0.0 & 0 & 0.0 & 169 \\
\hline
\end{tabular}
attitude berada pada kategori yang memberikan pengaruh dalam meningkatkan kualitas pelayanan hotel di Kota Makassar dan Parepare.

Tabel 4 Rekapitulasi Jawaban Responden tentang Behavior 


\begin{tabular}{cccccccccccc}
\hline Behavior3 & 17 & 44.7 & 21 & 55.3 & 0 & 0.0 & 0 & 0.0 & 0 & 0.0 & 169 \\
\hline Behavior4 & 26 & 68.4 & 12 & 31.6 & 0 & 0.0 & 0 & 0.0 & 0 & 0.0 & 178 \\
\hline Behavior5 & 26 & 68.4 & 12 & 31.6 & 0 & 0.0 & 0 & 0.0 & 0 & 0.0 & 178 \\
\hline Behavior6 & 26 & 68.4 & 12 & 31.6 & 0 & 0.0 & 0 & 0.0 & 0 & 0.0 & 178 \\
\hline & & \multicolumn{7}{c}{ Total Skor } & & & \\
\hline
\end{tabular}

\section{Sumber: Kuesioner Penelitian, 2019}

Tabel 4 tanggapan responden terhadap hospitality pendekatan soft skills karyawan berdasarkan behavior dengan total skor 1050 atau rata-rata 175 dari 6 item pernyataan yang didapatkan dari 3 indikator. Adapun skor tertinggi untuk setiap item pernyataan diberi skor 5 dan skor terendah diberi skor 1 . Adapun skor maksimum untuk interpersonal sebagai berikut:

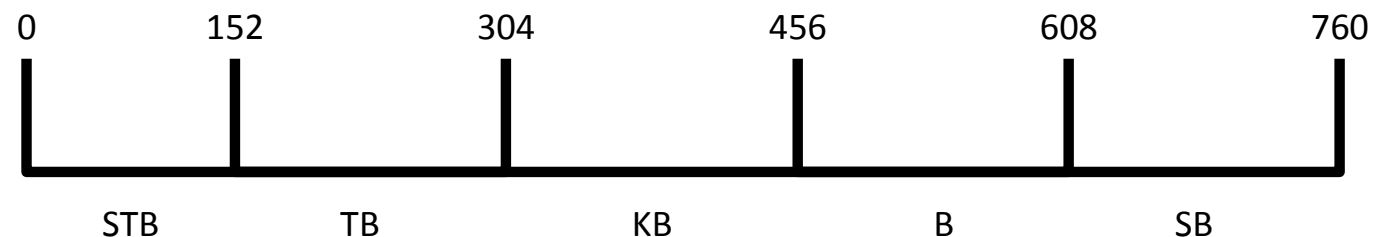

TB

B

SB

Skor Maksimum $=$ Skor Tertinggi Item Pernyataan $\mathrm{x} \mathrm{N}$ Item Pernyataan

= Skor Tertinggi (5) x N (38) x Item Pernyataan (4)

$=5 \times 38 \times 4$

$=760$

Berdasarkan penelitian hospitality pendekatan soft skills karyawan berupa behavior dalam meningkatkan kualitas pelayanan hotel di Kota Makassar dan Parepare, diperoleh total skor 1050, maka tanggapan dari 38 responden atas hal tersebut yaitu:

Skor Perolehan 1050

------------- x 100\% = ----- x 100\% = 138.2\%

Skor Maksimum $\quad 760$

Penilaian hospitality pendekatan softskills karyawan berupa behavior dalam meningkatkan kualitas pelayanan hotel > 100\%, secara kontinum dapat dibuat kategori sebagai berikut:
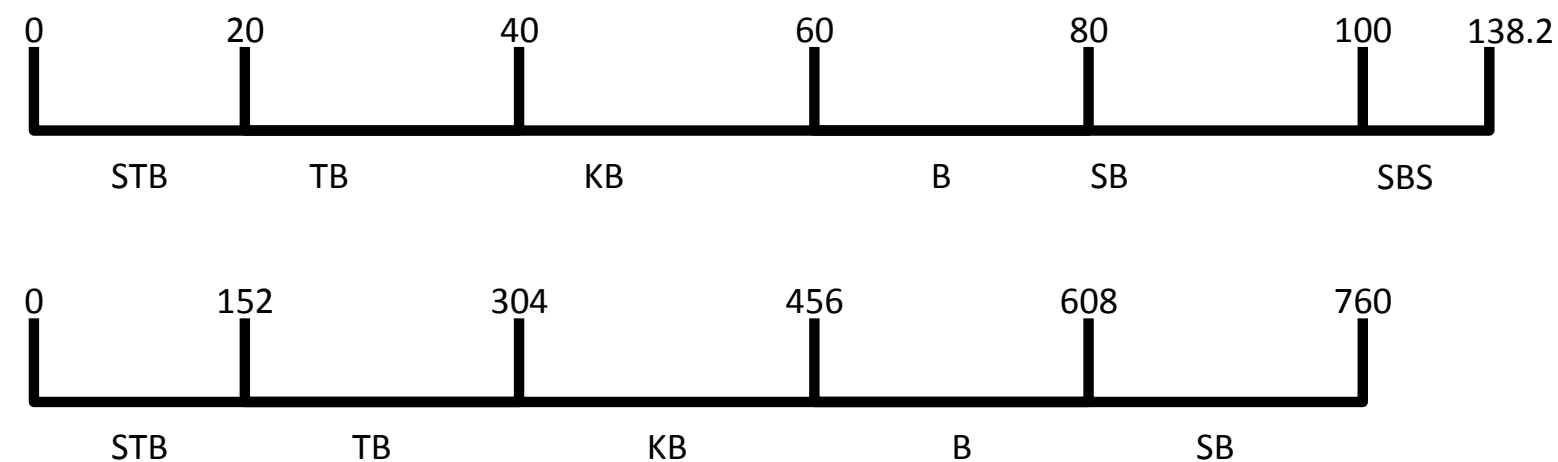


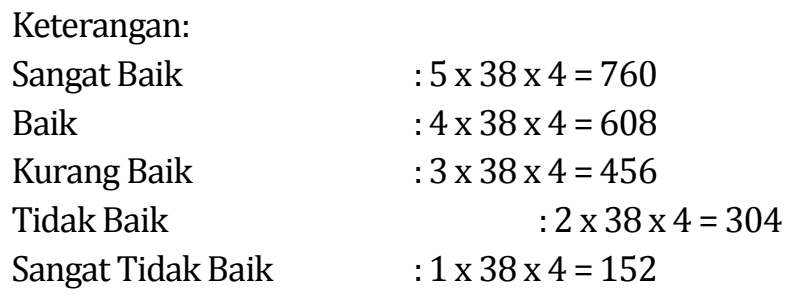

Hasil analisis di atas menunjukkan bahwa hospitality pendekatan soft skills karyawan berupa behavior berada pada kategori yang sangat baik sekali dan hal ini berarti karyawan hotel sangat menjaga perilakunya untuk tetap ramah dalam setiap memberikan pelayanan baik kepada tamu hotel, dengan khalayak, antar rekan kerja dan dengan pimpinan. Hospitality pendekatan soft skills karyawan berupa behavior memberikan pengaruh dalam meningkatkan kualitas pelayanan hotel di Kota Makassar dan Parepare.

Untuk melihat pengaruh hospitality pendekatan soft skills terhadap kualitas pelayanan hotel di Kota Makassar dan Parepare dilakukan dengan menggunakan model analisis regresi linier berganda. Pengujian variasi dari model regresi yang digunakan dalam menerangkan pengaruh variabel bebas (X) terhadap variabel terikat (Y) dengan cara menguji kemaknaan dari koefisien regresinya. Hasil perhitungan dengan menggunakan model regresi penuh (full model regression) diperoleh dengan nilai koefisien regresi pengaruh hospitality pendekatan soft skills berupa intrapersonal, interpersonal, attitude dan behavior terhadap kualitas pelayanan hotel.

Tabel 5 Rangkuman Hasil Uji-F Analisis Regresi Berganda

\begin{tabular}{cccccccc}
\hline Variable Regresi & Koefisien Regresi & R Square & Multiple R & Fratio & Ftable & Constanta & Sig. \\
\hline $\mathrm{X}_{1}$ & 0.698 & & & & & & \\
$\mathrm{X}_{2}$ & 0.836 & 0.916 & 0.839 & 21.215 & 4.9646 & 9.246 & 0.000 \\
$\mathrm{X}_{3}$ & 0.862 & & & & & & \\
$\mathrm{X}_{4}$ & 0.781 & & & & & & \\
\hline
\end{tabular}

Sumber : Lampiran Regresi, 2019

Besarnya pengaruh (kontribusi) variabel bebas (X) secara bersama-sama terhadap variabel terikat (Y) dapat dilihat dari besarnya koefisien determinan ganda $\left(\mathrm{R}^{2}\right)$. Nilai koefisien determinasi adalah diantara nol dan satu. Jika $\mathrm{R}^{2}$ yang diperoleh dari hasil perhitungan semakin besar (mendekati 1), maka dapat dikatakan pengaruh variabel bebas terhadap variabel tidak bebasnya semakin besar. Atau dengan kata lain, jika nilai yang mendekati satu berarti variabel-variabel independen memberikan hampir semua informasi yang dibutuhkan untuk memprediksi variasi variabel dependen.

Sebaliknya, jika R² yang diperoleh dari hasil perhitungan semakin kecil (mendekati 0), maka dapat dikatakan pengaruh variabel bebas terhadap variabel terikat semakin kecil. Atau dengan kata lain, nilai $\mathrm{R}^{2}$ yang kecil berarti kemampuan variabel-variabel independen dalam menjelaskan variasi variabel dependen amat terbatas.

Uji statistik F atau uji signifikansi simultan, pada dasarnya menunjukkan apakah semua variabel bebas yang dimasukkan dalam model mempunyai pengaruh secara bersama-sama terhadap variabel dependen. Uji F ini dilakukan dengan membandingkan Fhitung dengan nilai Ftabel pada taraf nyata $\alpha=$ 0,05. Uji F mempunyai pengaruh signifikan apabila Fhitung lebih besar dari Ftabel atau probabilitas kesalahan kurang dari 5\% ( $\mathrm{P}<0,05)$.

Dari hasil perhitungan analisis regresi linier berganda dengan bantuan program SPSS diperoleh $F_{\text {hitung }}$ sebesar 21.215 dengan tingkat probabilitas 0.000 (signifikan). Sedangkan $F_{\text {tabel }}$ sebesar 4.9646

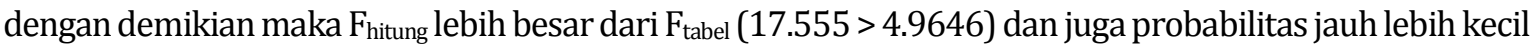
dari 0.05 , berarti bahwa hospitality pendekatan soft skills yang terdiri atas intrapersonal, interpersonal, 
attitude dan behavior secara simultan berpengaruh terhadap kualitas pelayanan hotel di Kota Makassar dan Parepare.

Selanjutnya uji t untuk menguji kemaknaan atau keberartian koefisien regresi partial. Pengujian melalui uji t adalah dengan membandingkan $t_{\text {hitung }}$ dengan $t_{\text {tabel }}$ pada taraf nyata $\alpha=0.05$. Uji t berpengaruh signifikan apabila hasil perhitungan $t_{\text {hitung }}$ lebih besar dari $t_{\text {tabel }}\left(t_{\text {hitung }}>t_{\text {tabel }}\right)$ atau probabilitas kesalahan lebih kecil dari 5\% $(\mathrm{p}<0.05)$. Lebih jelasnya ditunjukkan pada Tabel 4.19 disajikan hasil perhitungan uji t dan koefisien determinasi partialnya sebagai berikut:

Tabel 6 Hasil Perhitungan Uji Student (Uji-t)

\begin{tabular}{cccccc} 
Variabel Regresi & Koefisien Regresi & $t_{\text {hitung }}$ & t tabel & Sig. & Keterangan \\
\hline $\mathrm{X}_{1}$ & 0.698 & 3.878 & 1.7613 & 0.021 & Signifikan \\
$\mathrm{X}_{2}$ & 0.836 & 4.332 & 1.7613 & 0.000 & Signifikan \\
$\mathrm{X}_{3}$ & 0.862 & 4.353 & 1.7613 & 0.000 & Signifikan \\
$\mathrm{X}_{4}$ & 0.781 & 3.964 & 1.7613 & 0.018 & Signifikan \\
\hline
\end{tabular}

Sumber: Lampiran Regresi, 2019

Berdasarkan tabel 6, pengujian hospitality pendekatan soft skills yang berpengaruh terhadap kualitas pelayanan hotel di Kota Makassar dan Parepare dijabarkan sebagai berikut:

a. Intrapersonal $\left(\mathrm{X}_{1}\right)$, nilai $t_{\text {hitung }}=3.878$ dan $t_{\text {tabel }}=1.7613$, maka $t_{\text {hitung }}$ lebih besar dari $t_{\text {tabel }}$ $(3.878>1.7613)$ dengan Sig. 0.021 lebih kecil dari 0.05, berarti hospitality pendekatan soft skill berupa intrapersonal $\left(\mathrm{X}_{1}\right)$ berpengaruh terhadap kualitas pelayanan hotel.

b. Interpersonal $\left(\mathrm{X}_{2}\right)$, nilai $t_{\text {hitung }}=4.332$ dan $t_{\text {tabel }}=1.7613$, maka $t_{\text {hitung }}$ lebih besar dari $t_{\text {tabel }}$ (4.332 > 1.7613) dengan Sig. 0.000 lebih kecil dari 0.05, berarti hospitality pendekatan soft skill berupa interpersonal $\left(\mathrm{X}_{2}\right)$ berpengaruh terhadap kualitas pelayanan hotel.

c. Attitude $\left(\mathrm{X}_{3}\right)$, nilai $\mathrm{t}_{\text {hitung }}=4.353$ dan $\mathrm{t}_{\text {tabel }}=1.7613$, maka $\mathrm{t}_{\text {hitung }}$ lebih besar dari $\mathrm{t}_{\text {tabel }}$ $(4.353>1.7613)$ dengan Sig. 0.000 lebih kecil dari 0.05, berarti hospitality pendekatan soft skill berupa attitude $\left(\mathrm{X}_{3}\right)$ berpengaruh terhadap kualitas pelayanan hotel.

d. Behavior $\left(\mathrm{X}_{4}\right)$, nilai thitung $=3.964$ dan tabel $=1.7613$, maka thitung lebih besar dari tabel $(3.964>1.7613)$ dengan Sig. 0.018 lebih kecil dari 0.05, berarti hospitality pendekatan soft skill berupa behavior $\left(\mathrm{X}_{4}\right)$ berpengaruh terhadap kualitas pelayanan hotel.

Hasil perhitungan terlihat bahwa keseluruhan variabel yang diamati signifikan, artinya $t_{\text {hitung }}>t_{\text {tabel }}$, dan ditemukan pengaruh hospitality pendekatan soft skills berupa attitude $\left(\mathrm{X}_{3}\right)$ yang dominan berpengaruh atau yang lebih berpengaruh terhadap kualitas pelayanan hotel di Kota Makassar dan Parepare. Hal ini didasarkan pada koefisien regresi nilai B sebesar 0.862, yang menunjukkan cara bersikap dari karyawan hotel merupakan bentuk hospitality pendekatan soft skills yang menentukan kualitas pelayanan hotel di Kota Makassar dan Parepare.

Penelitian ini menguatkan sejumlah temuan tentang pengaruh pelayanan dengan pendekatan soft skill terhadap kualitas pelayanan. Kualitas pelayanan berpengaruh positif signifikan terhadap terhadap kepuasan tamu di Hotel Niagara Parapat Provinsi Sumatera Utara (Destiana Baetie, 2018). Penelitian ini menemukan bahwa hasil analisis regresi linier berganda $Y=3,341+0,306 \times 1+0,012 \times 2+0,205 \times 3+$ $0,388 \times 4+0,166 \times 5+$ e. F hitung $(43,587)>F$ tabel $(2,311)$ dengan signifikan $(0,000)<0,05$. Nilai koefisien determinasi (R2) adalah 69,9\% dan 30,1\% dipisahkan oleh faktor-faktor lain yang tidak termasuk dalam model regresi ini.

Keterampilan memiliki dampak positif terhadap kinerja pelayanan. (Hanafi, Ibrahim. 2018) Keterampilan memiliki dampak positif dan langsung yang signifikan terhadap kinerja layanan. Peran pengalaman pelanggan sebagai mediator antara kompetensi karyawan dan kinerja layanan tidak signifikan. Keterampilan karyawan sangat penting untuk kinerja yang lebih baik dalam bisnis jasa. 


\section{SIMPULAN}

Hospitality karyawan dengan pendekatan soft skill secara intrapersonal, interpersonal, attitude dan behavior telah diterapkan karyawan dan memberikan pengaruh yang positif dan signifikan baik secara simultan maupun parsial terhadap peningkatan kualitas pelayanan hotel di Kota Makassar dan Parepare.

Hasil analisis menunjukkan keseluruhan variabel yang diamati berupa intrapersonal, interpersonal, attitude dan behavior adalah signifikan berdasarkan perolehan nilai thitung $>$ ttabel, dan ditemukan pengaruh hospitality pendekatan soft skills berupa attitude (X3) yang dominan berpengaruh atau yang lebih berpengaruh terhadap kualitas pelayanan hotel di Kota Makassar dan Parepare. Hal ini didasarkan pada koefisien regresi nilai B sebesar 0.862, yang menunjukkan cara bersikap dari karyawan hotel merupakan bentuk hospitality pendekatan soft skills yang menentukan kualitas pelayanan hotel di Kota Makassar dan Parepare.

\section{DAFTAR REFERENSI}

Ahmad, A., \& Ridwan, M. (2019). Mengukur tingkat kepuasan mahasiswa terhadap layanan program studi manajemen divisi kamar politeknik pariwisata makassar. Jurnal Kepariwisataan Dan Hospitalitas, 3(2), 120-132.

Curtis, D. D. (2010). Defining, assessing and measuring generic competences. Adelaide: Flinders University, School of Education.

Fitria, A., \& Atalina, T. M. M. (2016). Pentingnya Peranan Skill dan Menu Knowledge Waiter/Waiters Terhadap Kepuasan Pelanggan di Food and Beverage Service Departement. Jurnal Pariwisata Pesona, 1(1).

Gordin, V., Trabskaya, J., \& Zelenskaya, E. (2016). The role of hotel restaurants in gastronomic place branding. International Journal of Culture, Tourism and Hospitality Research, 10(1), 81-90. https://doi.org/10.1108/IJCTHR-05-2015-0049

Ivanovic. M. (2009). Tourism Development Fresh Perspectives. New Jersey: Pearson Education and Prentice Hall.

Kechagias, K. (2011). Teaching and assessing soft skills. MASS Project, September.

Mahfud, T., Kusuma, B. J., \& Mulyani, Y. (2017). Soft skill competency map for the apprenticeship programme in the Indonesian balikpapan hospitality industry. Journal of Technical Education and Training, 9(2).

Musawantoro, M., \& Ridwan, M. (2019). Potensi Pantai Panrangluhung di Bira Kabupaten Bulukumba sebagai Destinasi Wisata. Jurnal Kepariwisataan: Destinasi, Hospitalitas Dan Perjalanan, 3(1), 1-7. https://doi.org/10.34013/jk.v3i1.27

Prastowo, I. (2017). Hotel Hygiene dan Sanitation. Sleman: CV Budi Utama.

Rotmianto, M. (2016). Konsep Hard Skill, Soft Skill Dan Spiritual Skill Pustakawan Menghadapi Era Library 3.0. Pustakaloka, 7(1), 79-92.

Sinangjoyo, N. J. (2013). Green Hotel Sebagai Daya Saing Suatu Destinasi. Jurnal Nasional Pariwisata, 5(2), 83-93.

Soekarno, \& Pendit. (1998). Pramusaji Food \& Beverage Service. Jakarta: PT Gramedia.

Suardana, W., Suni, M., \& Ridwan, M. (2019). The Influence of Room Prices and Promotion Costs on Hotel Room Occupancy Rates in Palopo City, South Sulawesi. Jurnal Ad'ministrare, 6(2), 123-130.

Sugiyono. (2010). Metode Penelitian Pendidikan Pendekatan Kuantitatif, kualitatif, dan R\&D. Bandung: Alfabeta.

Suryadharma, I. W. W., \& Nurcahya, I. K. (2015). Pengaruh kualitas pelayanan pada kepuasan pelanggan hotel Bintang Pesona di Denpasar Timur. E-Jurnal Manajemen, 4(4). 
Talavera, E. R., \& Pérez-González, J. C. (2007). Formación en competencias socioemocionales a través de las prácticas en empresas. Revista Europea de Formación Profesional, (40), 92112.

Zaenal, F. A. (2018). Pengaruh Getok Tular Elektronik Terhadap Minat Berkunjung Wisatawan di Kota Makassar. Jurnal Kepariwisataan, 2(1), 21-38. 